\title{
PENGETAHUAN, SIKAP, DAN PRAKTIK PENGGUNAAN OBAT TETES MATA KORTIKOSTEROID
}

\author{
Naufal Dhifari Ramadhan, Farah Mahdiyyah, Titania Fiska Ornelia, Wardah Zuhan Nafikhah, Ursulla \\ Yulananda Anugraheni, Mohammad Hefni Hidayat, Antonius Gamma Wardana, Rika Uyunul Mabilla, \\ Muharrom Riezky Prasetyo, Fakhriatun Nisa, I Nyoman Wijaya*
}

Departemen Farmasi Komunitas, Fakultas Farmasi, Universitas Airlangga

Gedung Nanizar Zaman Joenoes Kampus C, Jl. Ir. Soekarno, Surabaya 60115, Indonesia

E-mail: i-nyoman-w@ff.unair.ac.id

\begin{abstract}
ABSTRAK
Obat tetes mata kortikosteroid merupakan golongan obat tetes mata yang dapat diperoleh di apotek tanpa resep dokter. Obat ini banyak digunakan oleh masyarakat untuk swamedikasi, padahal penggunaan kortikosteroid dalam jangka waktu lama dapat menyebabkan glaukoma. Penelitian ini dilakukan untuk mengetahui profil pengetahuan, sikap, dan praktik pengguna obat tetes mata yang mengandung kortikosteroid pada masyarakat di sekitar Kelurahan Dupak. Survei ini merupakan penelitian deskriptif dengan metode sampling terpilih adalah teknik non-random sampling jenis accidental sampling. Pengambilan data dilakukan di Kelurahan Dupak dengan cara survei menggunakan kuesioner. Kuesioner berisikan 9 pernyataan benar atau salah untuk kategori pengetahuan, 5 pernyataan untuk kategori sikap dengan 4 skala Likert (sangat tidak setuju, tidak setuju, setuju, dan sangat setuju) serta 10 pernyataan untuk kategori praktik dengan 5 skala Likert (tidak pernah, jarang, kadang-kadang, sering, dan selalu) yang telah tervalidasi dengan validasi rupa oleh 40 responden. Jumlah responden pada survei ini adalah 100 orang. Survei dari 39 responden laki-laki dan 61 responden perempuan diperoleh $64 \%$ responden memiliki pengetahuan cukup, $67 \%$ memiliki sikap yang cukup, dan 55\% memiliki praktik yang cukup. Pengetahuan, sikap dan praktik pengguna obat tetes mata yang mengandung kortikosteroid di Kelurahan Dupak tergolong cukup.
\end{abstract}

Kata kunci: Tetes mata, kortikosteroid, glaukoma

\begin{abstract}
Corticosteroid eye drops are a class of eye drops that can be obtained at pharmacy without prescription. This drug is widely used by the public for self-medication, whereas long-term use of corticosteroids can cause glaucoma. This study was aimed to find out the profile of knowledges, attitudes, and practices in using corticosteroid eye drops in Kelurahan Dupak. This survey was a descriptive study with accidental sampling of non-random sampling technique as selected sampling method. Data was collected in Kelurahan Dupak by survey using a questionnaire. The questionnaire contained 9 statements of true or false for the knowledge category, 5 statements for the attitude category using 4 Likert scale(strongly disagree, disagree, agree, and strongly agree) and 10 statements for the practice category using 5 Likert scale (never, rarely, sometimes, very often, and always) that had been validated with form validation by 40 respondents. The amount of respondents in this study were 100 respondents. The survey results from 39 males and 61 femalesshowed that $64 \%$ of respondents have moderate knowledges, $67 \%$ have moderate attitudes, and $55 \%$ have moderate practices. Knowledge, attitude, and practice in using corticosteroid eye drops in Kelurahan Dupak are moderate.
\end{abstract}

Keywords: Eye drops, corticosteroid, glaucoma. 


\section{PENDAHULUAN}

Gangguan mata seperti mata merah, mata gatal, mata perih dan mata kering, semakin banyak dijumpai di masyarakat (Adrian, 2019). Penderitanya pun tidak terbatas pada usia tertentu. Berbagai penelitian menunjukkan bahwa adanya gangguan penglihatan bisa mengakibatkan penurunan kualitas hidup seseorang, yang terlihat dari berkurangnya kemampuan seseorang tersebut untuk melakukan pekerjaan, mengisi waktu luang, atau melakukan aktivitas harian (Asrorudin, 2013). Penyebab timbulnya gangguan mata antara lain karena faktor lingkungan dan gaya hidup (Klein dan Klein, 2007). Untuk mengatasi hal tersebut, maka diperlukan pengobatan. Selama ini, pengobatan mata yang sering dilakukan di masyarakat adalah dengan menggunakan obat tetes mata (Natalia dkk., 2014). Namun, banyak orang yang menggunakan obat tetes mata yang dijual bebas di apotek tanpa berkonsultasi dulu ke dokter (Swari, 2017).Salah satu kandungan bahan aktif dalam obat tetes mata yang paling banyak digunakan adalah kortikosteroid. Namun dalam penggunaannya, seseorang perlu berkonsultasi ke dokter karena pemakaian obat tetes mata yang mengandung kortikosteroid tidak untuk jangka panjang (Otcadm, 2018). Pemakaian steroid dengan rute topikal, periokular, intravitreal, inhalasi maupun sistemik dalam jangka waktu yang lama bisa memicu terjadinya glaukoma (American Academy of Ophthalmology, 2011).

Glaukoma adalah penyakit mata akibat kerusakan saraf optik yang diikuti gangguan pada lapang pandang yang khas. Kondisi ini disebabkan oleh hambatan pengeluaran cairan bola mata (aqueous humour) sehingga tekanan bola mata meninggi (Kemenkes RI, 2019). Penyakit ini adalah salah satu penyakit mata dengan prevalensi yang tinggi.Pada tahun 2017, jumlah kasus baru glaukoma pada pasien rawat jalan di rumah sakit di Indonesia adalah 80.548 kasus (Kemenkes RI, 2019). Menurut hasil Riset Kesehatan Dasar tahun 2007, persentase responden yang pernah didiagnosis glaukoma oleh tenaga kesehatan di wilayah Jawa Timur sebesar 0,5\% (Kemenkes RI, 2019), sedangkan menurut Persatuan Dokter Spesialis Mata Indonesia, jumlah pasien penderita glaukoma pada Juli 2013-Juni 2014 di Rumah Sakit Dr. Soetomo Surabaya sebanyak 4.260 pasien dan di Rumah Sakit Undaan Surabaya sebanyak 2.148 pasien (Kemenkes RI, 2019). Dalam sepuluh tahun terakhir, prevalensi glaukoma meningkat pesat seiring dengan pertumbuhan populasi dan pertumbuhan usia penduduk. Pada tahun 2010, jumlah penderita glaukoma di dunia mencapai 60,5 juta individu. Pada tahun 2020 kejadian glaukoma secara global akan mencapai angka 76 juta dan pada tahun 2040 akan mencapai angka 111,8 juta (Kemenkes RI, 2019).

Kortikosteroid yang diberikan secara oral, intravena, atau topikal telah dikaitkan dengan peningkatan risiko perkembangan glaukoma bila penggunaannya dalam jangka panjang (Olonan, 2009). Menurut pakar Dokter Spesialis Mata UGM, pemakaian steroid yang tidak beraturan dan dalam jangka panjang dapat menyebabkan glaukoma permanen bahkan kebutaan. Hal ini didukung data dari WHO yang menyatakan hampir 90\% kebutaan di dunia terdapat di Asia dan Afrika, sepertiganya di Asia Tenggara dengan salah satu penyebab utamanya adalah glaukoma dengan persentase 0,16\%. (Grehenson, 2007).

Jumlah penduduk di Kelurahan Dupak, Kecamatan Krembangan, Kota Surabayaper Januari 2018 dilaporkan sebesar 25.205 jiwa dengan mayoritas pendidikan kepala keluarga tidak tamat SD. Jumlah apotek di Kecamatan Krembangan mencapai 26 apotek (Badan Pusat Statistika Kota Surabaya, 2018) sehingga mempermudah akses penduduk untuk mendapatkan obat tetes mata kortikosteroid. Oleh karena itu ingin dilakukan survei di Kelurahan Dupak untuk mengetahui pengetahuan, sikap, dan praktik masyarakat di Kelurahan Dupak mengenai penggunaan obat tetes mata kortikosteroid.

\section{METODE}

\section{Desain penelitian}

Penelitian ini termasuk jenis penelitian deskriptif dengan pendekatan cross sectional yang bertujuan untuk mengetahui profil pengetahuan, sikap, dan praktik pengguna obat tetes mata yang mengandung kortikosteroid pada masyarakat di sekitar Kelurahan Dupak. Pengambilan data dilaksanakan pada tanggal 13-17 September 2019.

Metode sampling terpilih adalah teknik non-random sampling jenis accidental sampling, dengan jumlah responden sebanyak 100 orang. Kriteria inklusi pada penelitian ini adalah warga yang pernah atau sedang memakai tetes mata kortikosteroid, berdomisili di wilayah Kelurahan Dupak, berusia minimal 12 tahun, memahami Bahasa Indonesia, serta dapat membaca dan menulis. 


\section{Instrumen survei}

Kuesioner yang dirancang dibagi menjadi 4 kategori pertanyaan, antara lain: demografi, pengetahuan, sikap, dan praktik. Untuk kategori demografi terdiri atas jenis kelamin, usia, riwayat pendidikan, pekerjaan, dan riwayat penyakit. Untuk kategori pengetahuan berisikan 9 pertanyaan benar atau salah. Untuk kategori sikap berisikan 5 pertanyaan dengan 4 skala Likert (sangat tidak setuju, tidak setuju, setuju, dan sangat setuju). Untuk kategori praktik berisikan 10 pertanyaan dengan 5 skala Likert (tidak pernah, jarang, kadang-kadang, sering, dan selalu) yang telah tervalidasi dengan validasi rupa oleh 40 responden.

Data yang dikumpulkan dari responden kemudian diolah menggunakan Software Statistical Package for the Social Sciences (SPSS) versi 16.0. Data demografi responden, penilaian pengetahuan, sikap, dan praktik responden dianalisis menggunakan descriptive statistics. Data hubungan demografi responden dengan pengetahuan, sikap, dan praktik responden dianalisis menggunakan analisis correlation.

\section{HASIL DAN PEMBAHASAN}

\section{Demografi Responden}

Berdasarkan hasil survei yang telah dilakukan terhadap 100 responden (Tabel 1) diperoleh data demografi responden berdasarkan usia bervariasi mulai usia 10 tahun hingga lebih dari 60 tahun dengan jumlah terbanyak berasal dari rentang usia 31-50 tahun. Pada rentang usia tersebut, seorang manusia berada pada masa produktif, dimana intensitas kegiatan seseorang sangat tinggi sehingga menjadi rentan terhadap berbagai gangguan kesehatan termasuk pada mata. Demografi responden berdasarkan jenis kelamin menunjukkan bahwa perempuan lebih sering menggunakan obat tetes mata yang mengandung kortikosteroid.Hal tersebut dikarenakan pada wanita akan terjadi perubahan fungsi penglihatan, misalnya saat kehamilan dan pasca menopause (Ilyas, 2007) serta akibat sudut bilik mata depan perempuan lebih dangkal daripada laki-laki.

Demografi responden berdasarkan riwayat pendidikan dan pekerjaan menunjukkan bahwa kebanyakan pengguna obat tetes mata yang mengandung kortikosteroid merupakan tamatan SMA dan bekerja di bidang swasta. Pekerja swasta memiliki intensitas kerja di luar ruangan yang cenderung lebih tinggi daripada pekerjaan lain sehingga lebih sering berkontak dengan debu dan polutan. Selain itu, kebanyakan pengguna obat tetes mata yang mengandung kortikosteroid tidak memiliki riwayat penyakit lain sebelumnya.

Tabel 1. Gambaran Demografi Responden

\begin{tabular}{|c|c|c|}
\hline \multicolumn{2}{|c|}{ Demografi } & $\mathrm{n}(\%)$ \\
\hline \multirow{6}{*}{$\begin{array}{l}\text { Usia } \\
\text { (tahun) }\end{array}$} & $10-20$ & $10(10 \%)$ \\
\hline & $21-30$ & $10(10 \%)$ \\
\hline & $31-40$ & $29(29 \%)$ \\
\hline & $41-50$ & $29(29 \%)$ \\
\hline & $51-60$ & $12(12 \%)$ \\
\hline & $\geq 60$ & $10(10 \%)$ \\
\hline \multirow{2}{*}{$\begin{array}{c}\text { Jenis } \\
\text { Kelamin }\end{array}$} & Laki-laki & $39(39 \%)$ \\
\hline & Perempuan & $61(61 \%)$ \\
\hline \multirow{5}{*}{$\begin{array}{l}\text { Riwayat } \\
\text { Pendidikan }\end{array}$} & SD & $17(17 \%)$ \\
\hline & SMP & $16(16 \%)$ \\
\hline & SMA & $49(49 \%)$ \\
\hline & Diploma & $4(4 \%)$ \\
\hline & Sarjana & $9(9 \%)$ \\
\hline \multirow{5}{*}{ Pekerjaan } & Tidak Bekerja & $7(7 \%)$ \\
\hline & Ibu Rumah Tangga & $28(28 \%)$ \\
\hline & PNS & $1(1 \%)$ \\
\hline & Swasta & $55(55 \%)$ \\
\hline & Pelajar & $9(9 \%)$ \\
\hline \multirow{7}{*}{$\begin{array}{l}\text { Riwayat } \\
\text { Penyakit }\end{array}$} & Tidak Ada & $68(68 \%)$ \\
\hline & Hipertensi & $6(6 \%)$ \\
\hline & Hipotensi & $1(1 \%)$ \\
\hline & Sakit Mata & $8(8 \%)$ \\
\hline & Diabetes Mellitus & $2(2 \%)$ \\
\hline & Lain-lain & $15(15 \%)$ \\
\hline & Total & $100(100 \%)$ \\
\hline
\end{tabular}

Pengetahuan, Sikap, dan Praktik Pengguna Obat Tetes Mata yang Mengandung Kortikosteroid pada Responden

Berdasarkan hasil survei pada Tabel 2 diperoleh bahwa untuk aspek pengetahuan, sikap, dan praktik, sebagian besar responden memperoleh skor masing masing 4-6, 11-15, dan 24-37. Hal ini menunjukkan bahwa responden memiliki pengetahuan, sikap, dan praktik dalam kategori cukup mengenai penggunaan obat tetes mata yang mengandung kortikosteroid.

Tabel 2. Penilaian Pengetahuan, Sikap, dan Praktik Pengguna Obat Tetes Mata yang Mengandung Kortikosteroid

\begin{tabular}{ccccc}
\hline $\begin{array}{c}\text { Aspek } \\
\text { Penilaian }\end{array}$ & Skor & $\begin{array}{c}\text { Jumlah } \\
\text { Responden }\end{array}$ & $\begin{array}{c}\mathrm{n} \\
(\%)\end{array}$ & Kategori \\
\hline \multirow{3}{*}{ Pengetahuan } & $1-3$ & 10 & 10 & Kurang \\
\cline { 2 - 5 } & $4-6$ & 64 & 64 & Cukup \\
\cline { 2 - 5 } Sikap & $7-9$ & 26 & 26 & Tinggi \\
\hline \multirow{3}{*}{ Praktik } & $5-10$ & 2 & 2 & Kurang \\
\cline { 2 - 5 } & $11-15$ & 67 & 67 & Cukup \\
\cline { 2 - 5 } & $16-20$ & 31 & 31 & Tinggi \\
\hline \hline & $10-23$ & 2 & 2 & Kurang \\
\hline & $24-37$ & 55 & 55 & Cukup \\
\hline \hline
\end{tabular}


Hubungan Demografi dengan Pengetahuan, Sikap, dan Praktik Pengguna Obat Tetes Mata yang Mengandung Kortikosteroid

Hasil analisis statistika dari data yang diperoleh (Tabel 3) menunjukkan bahwa tidak ada hubungan antara usia dengan pengetahuan, sikap dan praktik pengguna obat tetes mata yang mengandung kortikosteroid. Hasil ini tidak sesuai dengan penelitian Widyatun, (2009), yang menyebutkan bahwa usia dapat berpengaruh terhadap daya tangkap dan pola pikir seseorang. Semakin bertambah usia seseorang maka semakin banyak pengalaman dan pengetahuan yang dimilikinya. Usia seseorang yang lebih dewasa memengaruhi tingkat kemampuan dan kematangan dalam berpikir serta menerima informasi yang lebih baik dibandingkan dengan usia lebih muda. Dengan pengetahuan yang baik maka idealnya seseorang juga memiliki sikap dan praktik yang baik.

Tabel 3. Penilaian Hubungan Demografi dengan Pengetahuan, Sikap, dan Praktik Pengguna Obat Tetes Mata yang Mengandung Kortikosteroid

\begin{tabular}{lcc}
\hline \hline \multicolumn{1}{c}{ Aspek Penilaian } & Sig. & Makna \\
\hline Usia - Pengetahuan & 0,374 & Tidak berhubungan \\
Usia-Sikap & 0,741 & Tidak berhubungan \\
Usia-Praktik & 0,581 & Tidak berhubungan \\
\hline J.K - Pengetahuan & 0,298 & Tidak berhubungan \\
J.K - Sikap & 0,875 & Tidak berhubungan \\
J.K - Praktik & 0,658 & Tidak berhubungan \\
\hline Pdd - Pengetahuan & 0,000 & Berhubungan \\
Pdd -Sikap & 0,431 & Tidak berhubungan \\
Pdd -Praktik & 0,024 & Berhubungan \\
\hline Pkj -Pengetahuan & 0,520 & Tidak berhubungan \\
Pkj -Sikap & 0,976 & Tidak berhubungan \\
Pkj - Praktik & 0,595 & Tidak berhubungan \\
\hline \hline
\end{tabular}

Keterangan :

$\mathrm{J} . \mathrm{K}=$ Jenis Kelamin

Pdd $=$ Pendidikan

Pkj = Pekerjaan

Pengetahuan, sikap dan praktik pengguna obat tetes mata yang mengandung kortikosteroid tidak memiliki hubungan dengan jenis kelamin.Hasil ini sesuai dengan penelitian Ifada, (2010), yang menyebutkan bahwa tidak ada hubungan antara jenis kelamin dengan pengetahuan.Namun ketiadaan hubungan antara jenis kelamin dengan sikap dan praktik bertentangan dengan Sunaryo, (2004), yang menyebutkan bahwa salah satu faktor yang memengaruhi seseorang berperilaku adalah jenis kelamin, di mana pemikiran perempuan lebih didasari faktor emosional sedangkan pada laki-laki lebih rasional.
Tidak ada hubungan antara pendidikan dengan pengetahuan dan praktik, namun pendidikan memiliki keterkaitan dengan sikap pengguna obat tetes mata yang mengandung kortikosteroid.Hasil ini tidak sesuai dengan penelitian Soekanto, (2002), yang menyatakan semakin tinggi pendidikan seseorang maka semakin mudah pula untuk menerima informasi dan pada akhirnya semakin banyak pengetahuan yang dimilikinya. Sebaliknya jika seseorang tingkat pendidikannya rendah, akan menghambat perkembangan sikap seseorang terhadap penerimaan informasi dan nilai-nilai baru. Tingkat pendidikan individu akan berpengaruh terhadap kemampuan berpikir. Semakin tinggi tingkat pendidikan akan semakin mudah untuk berpikir rasional dan menangkap informasi baru termasuk dalam hal menguraikan masalah. Individu yang berpendidikan tinggi diharapkan memiliki pengetahuan yang luas termasuk pengetahuan terhadap kebutuhan kesehatannya. Menurut Mubarak, (2007), salah satu faktor yang dapat mempengaruhi pengetahuan seseorang adalah jenjang pendidikan yang dimiliki oleh individu. Dimana semakin tinggi tingkat pendidikan seseorang, maka semakin tinggi pula tingkat pengetahuannya. Dikutip dari Soekanto (2002), pendidikan adalah sebuah proses belajar dan proses pertumbuhan, perkembangan atau perubahan ke arah yang lebih baik, lebih dewasa dan lebih matang terhadap individu, kelompok atau masyarakat. Meningkatnya pengetahuan dapat menimbulkan perubahan persepsi dan kebiasaan seseorang dan dapat membentuk kepercayaan seseorang terhadap penggunaan obat.

Pengetahuan, sikap dan praktik pengguna obat tetes mata yang mengandung kortikosteroid tidak memiliki hubungan dengan pekerjaan.Hal ini kurang sesuai dengan penelitian Wati, (2009), yang menyebutkan pada pekerjaan yang menuntut seseorang agar sering berinteraksi dengan orang lain akan memberikan lebih banyak pengetahuan baru dibandingkan pekerjaan dengan sedikit interaksi di dalamnya. Pengalaman belajar dalam bekerja dapat memberikan pengetahuan dan keterampilan profesional serta mengembangkan kemampuan pengambilan keputusan dengan pemikiran secara ilmiah dan etik.Hal ini secara tidak langsung dapat mendorong sikap dan praktik seseorang menjadi lebih baik. 


\section{KESIMPULAN}

Pengetahuan, sikap, dan praktik pengguna obat tetes mata yang mengandung kortikosteroid di Kelurahan Dupak tidak berhubungan dengan jenis kelamin dan pekerjaan. Hal tersebut berbeda dengan aspek pendidikan yang berpengaruh terhadap pengetahuan dan praktik namun tidak berpengaruh pada sikap pengguna obat tetes mata yang mengandung kortikosteroid. Hasil penelitian menunjukkan bahwa pengetahuan, sikap, dan praktik dari pengguna obat tetes mata yang mengandung kortikosteroid di Kelurahan Dupak tergolong kategori cukup.

\section{DAFTAR PUSTAKA}

Adrian, K. (2019). Inilah Penyakit Mata yang Umum terjadi. https://www.alodokter.com/inilah- penyakitmata-yang-umum-terjadi. diakses 18 September 2019.

American Academy of Ophthalmology. (2011). Basic and Clinical Science Course. San Francisco: American Academy of Ophthalmology.

Asrorudin, M. (2013). Dampak Gangguan Penglihatan dan Penyakit Mata Terhadap Kualitas Hidup Terkait Penglihatan (VisionRelated Quality Of Life) pada Populasi Gangguan Penglihatan Berat dan Buta Di Indonesia.Skripsi, Fakultas Kedokteran Universitas Indonesia,Jakarta.

Badan Pusat Statistik Kota Surabaya.(2018). Kecamatan Krembangan Dalam Angka. Surabaya: Badan Pusat Statistik.

Grehenson, G. (2007). Penggunaan Obat Tetes Mata Pada Anak Bisa Sebabkan Kebutaan. https://ugm.ac.id/id/berita/49-penggunaanobat- tetes-mata-pada-anak -bisa-sebabkankebutaan. Diakses 18 September 2019.

Ifada, I. (2010). Faktor-Faktor Yang Berhubungan dengan Pengetahuan Masyarakat Mengenai Pelayanan Kesehatan
Mata.Skripsi, Fakultas Kedokteran Universitas Diponegoro, Semarang.

Ilyas, S. (2007). Glaukoma (Tekanan Bola Mata Tinggi) Edisi 3. Jakarta: CV. Sagung Seto.

Kemenkes RI. (2019). Situasi Glaukoma di Indonesia INFODATIN. Jakarta: Pusat Data dan Informasi Kementerian Kesehatan RI.

Klein, B. E. K. dan Klein, R. (2007).Lifestyle Exposures and Eye Diseases in Adults.American Journal of Ophthalmology, 144(6), p. 961-969.

Mubarak, W. I. (2007).Promosi Kesehatan Sebuah Pengantar Proses Belajar Mengajar Dalam Pendidikan. Yogyakarta: Graha Ilmu.

Natalia, C., Ratih, P.S., dan Haswiyanti. (2014). Gambaran Tingkat Pengetahuan Pasien tentang Cara Penggunaan dan Penyimpanan Obat Tetes Mata di Apotek Perintis Kuripan Banjarmasin.Karya Tulis Ilmiah, Akademi Farmasi ISFI Banjarmasin, Banjarmasin.

Olonan, L. R., Pangilinan, C. A., Yacto, M. (2009). Steroid Induced Cataract and Glaucoma in Pediatric Patient with Nephritic Syndrome. Journal Ophthalmology, Vol. 34, p. $59-62$.

Otcadm, (2018). Jangan Asal Menggunakan Tetes Mata.http://otcdigest.id/topikkita/jangan-asal-menggunakan-tetes-mata. Accessed 27 September 2019,

Soekanto, S. (2002).Sosiologi Suatu Pengantar. Jakarta: CV.Rajawali

Sunaryo (2004).Psikologi Untuk Keperawatan. Jakarta : EGC.

Swari, and Risky, C. (2017).Hati-Hati, Sembarangan Pakai Obat Tetes Mata Bisa Sebabkan Kebutaan.https:

//hellosehat.com/pusat kesehatan/gangguanmata-dan-penglihatan/bahaya-obat-tetesmata-steroid/.Diakses 20 September 2019.

Wati, R. (2009). Pengaruh Penyuluhan Terhadap Peningkatan Pengetahuan Kesehatan Reproduksi Remaja di SMA PGRI 3 Purwakarta.Skripsi, Universitas Muhammadiyah Surakarta, Surakarta.

Widyatun, T. R. (2009). Ilmu Perilaku. Jakarta: CV. Sagung Seto. 